\title{
Assessing the effectiveness of a hybrid PPBL model of delivering Workshop Practice course for the first-year engineering students
}

\author{
Prashant S. Jadhav', Dhananjay G. Thombare ${ }^{2}$, P.M. Jadhav ${ }^{3}$, Sachin B. Khot ${ }^{4}$ \\ ${ }^{1,3,4}$ Department of Mechanical Engineering, Rajarambapu Institute of Technology, Sangli, Maharashtra \\ ${ }^{2}$ Department of Autombile Engineering, Rajarambapu Institute of Technology, Sangli, Maharashtra \\ ${ }^{1}$ prashant.jadhav@ ritindia.edu
}

\begin{abstract}
This paper presents cognizance of learning and change in attitude of first year engineering students who have participated in a Project and Product Based Learning (PPBL) approach to the course Workshop Practice. The traditional course 'Workshop Practice' was modified and implemented in the Rajarambapu Institute of Technology from Academic Year 2016-17. This course is compulsory for all branch students of first year engineering and is segmented into two bits viz; Workshop Practice I and Workshop Practice II, students are required to learn various workshop skills in first semester and based on the acquired skills, the PPBL hybrid approach in second semester will help them to conceptualize and fabricate small jobs of their interest, This not only will help students to learn engineering skills but some life skills too. The qualitative paradigm was found to be suitable for studying the process undergone by the students, mainly because the study focused on students' emotions, thoughts, behaviour, and difficulties. Data was collected by structured feedback of the students, the instructor, by observations during their work, and by analysing students' reports. The paper presents the transformation from Project Based Learning (PBL) to hybrid approach of Project and Product based learning (PPBL), students' cognizance of the aim of the course, the instructor's role in a PPBL approach; advantages of the PPBL from the students' point of view and PPBL as a learning environment for future engineers.
\end{abstract}

Keywords: Project and Product Based Learning, Workshop Practice

\section{Introduction:}

Workshop practice for engineering students is the backbone of the engineering which develops real industrial environment for students and helps to enhance relevant technical hand skills required by the technician working in the various engineering industries. This course gives an opportunity to students to enhance their skills in material selection, use of appropriate equipment's and tools, manufacturing practices and machine operations. For all budding engineers irrespective of their stream of engineering, the knowledge of workshop practices helps them in day-today industrial as well domestic life to solve various problems. The theory of workshop practices is to make students familiar with the variety of approaches to make variety of engineering gazettes and products to meet the desired requirements. Ultimate aim of an engineer is creating a product, gazette, solution to a problem or to system to provide or improve the service for better quality of life of people. In order to have overall development of budding engineers, it is necessary to integrate theory with practice and thus the workshop practice curriculum would help students to understand the entire procedure to make or manufacture a product from need to final product. The students are required to learn and develop these skills through this course.

The students during workshop practical are advised to undergo various skill sets with own experiences by remembrance, understanding and application with special emphasis on attitude of enquiry to know why and how for the various instructions and practices imparted to them in each shop. Besides these, the development of dignity of labor, precision, safety at work place, team working and development of right attitude are the other objectives of this course. [7]

\section{Transformation from PBL to PPBL:}

The benefits of experiential learning have been reported by educators, such as John Dewey, for over 100 years Experiential and hands-on learning has a long history in engineering education [1][2]. Industry requirements for engineering graduates evolve and demand changes to the educational approach used. Experiential learning, with its reflection on doing is the most likely answer to the new demands. Within that educational approach, problem-based and project-based learning stand as the most successful methods. They are widely regarded as effective and innovative methods for engineering education. [4]

The hybrid approach of project and product-based learning (PPBL), will prove incredible as it is ranging from typical inquiry-based learning, through problem-oriented lectures to completely open experiential learning. Projectbased learning (PPBL) has potentially evolved with two other, closely related methods: inquiry-based (or problem based) learning and experiential learning [1]. Some believe that project-based learning is problem-based learning by definition. [11] Problem-based learning was developed at McMaster University in Canada in the late 1960s [8]. 
Although PBL shares some overlapping characteristics with problem-based, PBL is designed to acknowledge the importance of standards and evaluation of student learning and its focus is on the application, and possibly the integration of previously acquired knowledge.

Both problem-based learning and project-based learning are widely regarded as a successful and innovative method for engineering education. Problem-based learning is driven by the problem that is encountered by the students and focuses on research and inquiry; it starts with a problem, and solving the problem becomes the main focus of the students.

In case of workshop practice, this can be further extended as Project and Product based learning (PPBL) as Students are supposed to visualize the product based on a need they find in their surroundings. This need of a product drives the process that begins with the assignment to accomplish, which indicates certain tasks leading to the production of the final product.

\section{Need of PPBL approach to Workshop Practice at First Year:}

The Accreditation Board for Engineering and Technology (ABET) has said that- "students should develop higher order thinking skills of analysis, synthesis and evaluation." [9] Sometimes, students do not find the relevance of what they are taught in real-life practice. Hence, there is a need to transform the way 21 st century students are educated and prepared for their future professional work.

Workshop Practice I and II are practical courses in First year engineering which traditionally involves demonstration and working on small jobs under the supervision of Instructor. These Courses are compulsory for all First Year Students. Over the Years, It has been observed that Soft branch students are less interested in workshop course as they find it cumbersome and incommodious. The major reason is the traditional approach of Workshop Practice course. so PPBL is a successful approach that addresses some of these challenges and needs in which students become active learners and participate in hands-on activities.

\section{Course Development:}

workshop curriculum was developed based on the today's needs. A special attention was given on skill transfer rather than traditional approach. For hard branch students, it is always seen that, this course helps to learn manufacturing processes and production technology courses in successive semesters so students are generally contended to carry out workshop tasks. On other hand, soft branch students are least interested in this lab course as they find difficult to correlate its practical application to their domain area. so, major focus during the course development was to know the proclivity of different engineering departments. In line with it, feedback was taken from Heads of department of soft branch departments and preference list was made of various sections of workshops. The choice was taken for approach that department wants their students to learn the specific skills. Based on the importance, choice was given by each department for either performance or demonstration as shown in the table 1 . This feedback helped to have orientation of course in peculiar way. skill sets which fresh graduates are required to hone to dodge obsolescence, are focused. All soft branch heads gave their opinion about every section of a workshop as per new trends set in their domain. For e.g. most of them said fitting and smithy shops are not of much importance but they find relevance of carpentry, plumbing and tin smithy in their domain. Computer engineers and IT engineers, if told the relevance of Tin smithy for CPU cabinet, Electrical engineers if told about relevance of plumbing in wiring, Electronics engineers if given relevance of welding, brazing and soldering with PCB, the curiosity of fresh graduating students remains on peak and they do not find it burdensome.

Table 1: Soft Branch preferences for workshop skills

\begin{tabular}{|c|c|c|c|c|c|}
\hline S.N. & Sections & Electrical & CSE & IT & Electronics \\
\hline $\mathbf{1}$ & $\begin{array}{c}\text { Machine } \\
\text { Shop }\end{array}$ & Demo & Demo & Demo & Demo \\
\hline $\mathbf{2}$ & Fitting & Demo & Demo & Demo & Demo \\
\hline $\mathbf{3}$ & Carpentry & Performance & Performance & Performance & Demo \\
\hline $\mathbf{4}$ & Smithy & Demo & Demo & Demo & Demo \\
\hline $\mathbf{5}$ & Welding & Performance & Performance & Demo & Performance \\
\hline $\mathbf{6}$ & $\begin{array}{c}\text { Tin } \\
\text { Smithy }\end{array}$ & Performance & Performance & Performance & Performance \\
\hline $\mathbf{7}$ & Plumbing & Performance & Performance & Demo & Performance \\
\hline
\end{tabular}

\section{Course Implementation}

The new developed course involves training the students in different sections of workshop in first semester namely machine shop, carpentry, welding, tin smithy and plumbing. Here, practicals are designed in such a way that students will utilize maximum resources in their turn, for e.g. Out of 12 turns of semester (weekly 1), practical distribution is made where more time is given to sections to which department has given the preference. Carpentry, Tin smithy, welding and plumbing are given 2 turns each in which small jobs are to be prepared in group of two. (Structured syllabus is attached in appendix)

In Second semester, based on the skills they acquire in first semester, students are supposed to decide an idea of a product depending on the need they find in their surroundings. After checking suitability, they conceptualize the product and later the size, shape and geometry of a product can be finalized. Further, material selection and manufacturing process can be decided. This process is carried out as shown in figure 1.

In this semester, students are supposed to select any two products which are further divided into two parts viz; In first 6 turns, they are supposed to prepare 1 product and 2nd product in next 6 turns. These 6 turns are planned in such a way, analytical skills of students, visualization and creativity is challenged. for e.g. In 1st turn, students are supposed to select product idea and get it sanctioned by instructor. following to that in 2nd turn, preparation of drawing, its approval and material selection has to be done. 


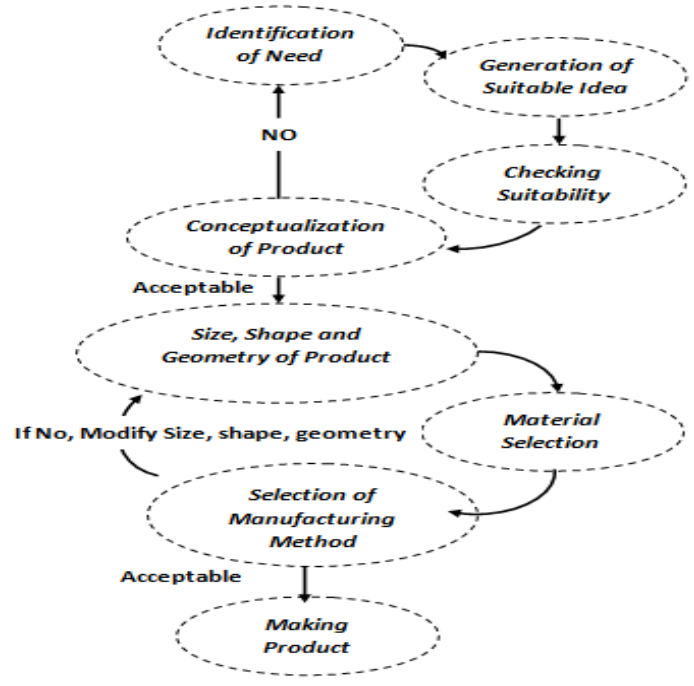

Figure 1. Flow of the workshop approach
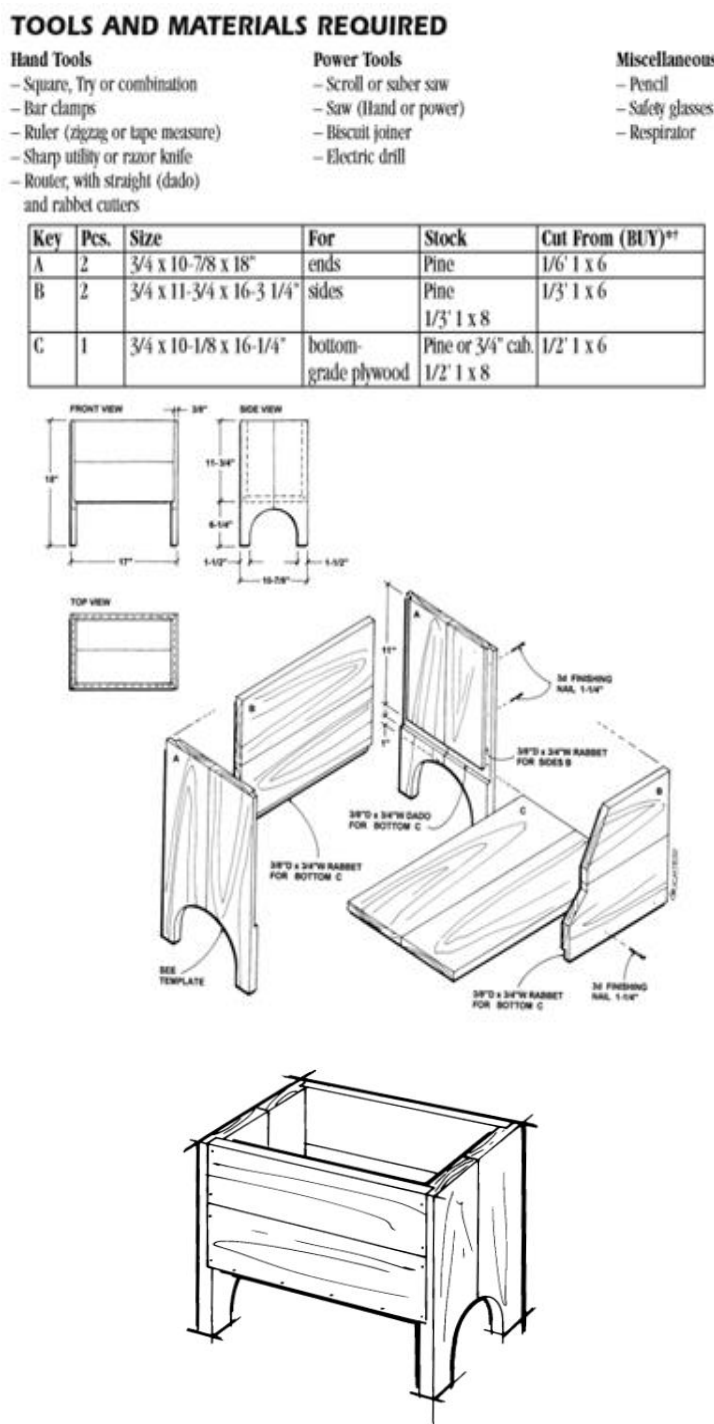

Figure: 2. Sample Detailed drawing and procurement plan

Here, students are required to prepare detailed drawing (Hand drawing, CAD or any other drawing softwares like Vectorworks, SketchUp) and material requirement has to be given as shown in figure 2 which shows sample drawing and procurement plan for magazine rack prepared by students. For this, discussion with instructor is very crucial as choice of material may be dexterous task.

Immediately, desired material is procured and in 3rd,4th and 5th turn, students have to make a product as per the drawing by using various operations in different sections of workshop. In 6th turn, assessment of prepared job is carried out. The same process is followed in next 6 turns for 2 nd product. Some sample product list is provided to students for reference but the choice of product is never restricted. moreover, the dimensions as well are to be decided by students as per the need for e.g. domestic motor cover, magazine rack, picture frames at various sites will differ in size and shape.

\section{Result and Discussion}

With an effective implementation of PPBL approach for workshop practice course, it is necessary to assess the effect of this hybrid model. This has been carried out in various stages viz; Grade analysis, feedback of students and also of instructors.

\subsection{Grade analysis}

There are 450 students in first year of engineering and following graph shows that with an application of PPBL in the year 2016-17, number of students in AA grade (score more than 90) have been improved. The year 2015 shows the number of AA grade students before implementation of PPBL to workshop. The grade analysis of students for this course is shown in figure 3 .

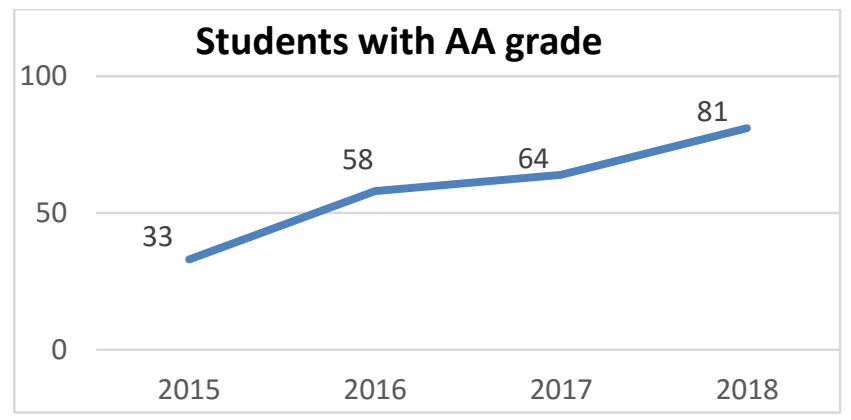

Figure: 3. Grade Analysis of students

\subsection{Feedback strategy}

Feedback is an essential element of the learning process. In its many forms, feedback allows students to reflect on their learning; clarifies area where students can be improved, curriculum orientation can be modified and it provides students the opportunity to self-assess their skills and capabilities. As feedback is designed to enhance curriculum, it is insufficient to only take feedback at the end of the module but to be effective, feedback needs to be a continuous process of conversation and reflection. [6] In view to this, Instructor's observations are also noted for the betterment of this course.

\subsection{Instructors' observations}


Initially the students did not take the activity seriously. However, as some of the students started rising up with their creativity, competition became tough among them. Later it was observed that almost all students were equally engaged in the activity and a sense of motivation factor was emerged to perform better and faster. It was found to be more towards satisfaction than earning credits.

Table 2: Instructor's Feedback rubrics

\begin{tabular}{|l|l|l|l|l|l|}
\hline \multicolumn{1}{|c|}{ Items } & $\begin{array}{c}\text { Strongly } \\
\text { Agree } \\
\text { (5) }\end{array}$ & $\begin{array}{c}\text { Agree } \\
\text { (4) }\end{array}$ & $\begin{array}{c}\text { Neutral } \\
\text { (3) }\end{array}$ & $\begin{array}{c}\text { Disagree } \\
\text { (2) }\end{array}$ & $\begin{array}{c}\text { Strongly } \\
\text { Disagree } \\
\text { (1) }\end{array}$ \\
\hline $\begin{array}{l}\text { The course shampened the analytical skills of } \\
\text { students. }\end{array}$ & & & & & \\
\hline $\begin{array}{l}\text { The students were more specific and goal } \\
\text { oriented with the passage of time. }\end{array}$ & & & & & \\
\hline $\begin{array}{l}\text { Students interest in PBL activity has increased } \\
\text { with time. }\end{array}$ & & & & & \\
\hline $\begin{array}{l}\text { This course has improved the creativity of } \\
\text { students. }\end{array}$ & & & & & \\
\hline $\begin{array}{l}\text { In my opinion, PBL approach of workshop is } \\
\text { better than traditional one. }\end{array}$ & & & & & \\
\hline
\end{tabular}

Feedback of 13 instructors were taken on 5 questions as shown in table 2 . This revealed that $62 \%$ of the instructors are agreed that the course improved the student's analytical skills i.e. Students can visualize the geometry of a product, dimensions and primary force calculations. based on that, they can select the materials. Similarly, $76 \%$ agreed that, students were more specific and goal-oriented with the passage of time. Moreover, $85 \%$ instructors opined that PBL approach to workshop is definitely better that the traditional system.

\subsection{Evidence of the effectiveness of PPBL}

There is need of documenting the effects of PPBL in order to prove its effectiveness. This research is needed not only to guide PPBL instruction and the development of projects, but also to provide justification for the dissemination and diffusion of PPBL practices across all branches of engineering. Students from various branches were asked specific set of questions and based on their responses, conclusion were made. These questions were designed to check the various perspectives of the students about new holistic approach towards workshop practice course.

A questionnaire (attached in appendix) was designed to evaluate the level of attainments of course outcomes of the workshop practice course I and II. The questions were asked to students and their opinions are taken for following parameters.

- Importance and relevance of the hand skills in engineering profession.

- Level of learning techniques, methods and processes to make a product / gazette during the course.

- familiarity of students to use the power tools for making a product.

- Level of skills and experience acquired to choose process for making a product.

- Knowledge of safety measures and their use while working on machines.
- Learning of the process to convert an idea into final product.

- Opportunity to explore their creative capacities through workshop practice.

- Capacity to make a product independently.

The responses were collected in following groups and the results and its effects are interpreted.

- Gender - Male, Female

- Program - Core branches and soft branches.

The level of student's understanding about importance and relevance of hand skills in engineering profession is shown in the figure 4 . The results show that newly designed course the level of understanding importance and relevance of hand skills in engineering profession is improved considerably.

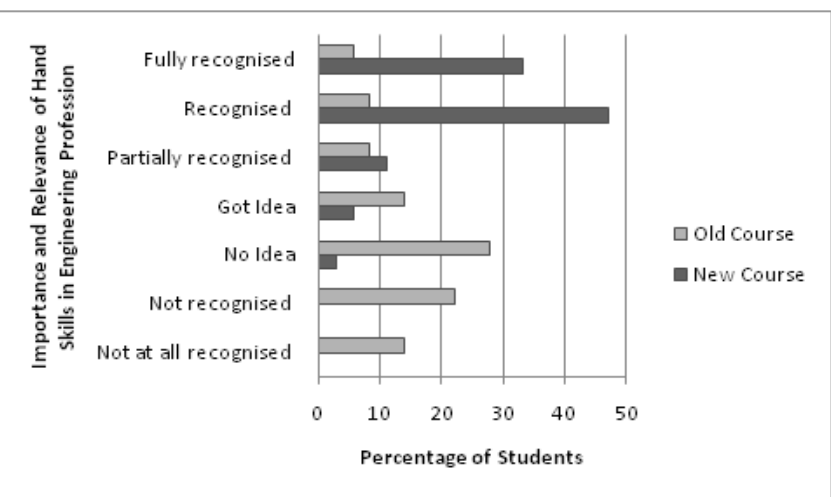

Figure: 4. Importance of hand skills in engineering

Majority of the students have understood the importance and relevance, and this is very useful outcome of the new course. From statistics, it can be said that student's approach towards workshop practice is changed. This is more relevant and important in soft branch students.

While designing the course, the care was taken that the students will learn techniques, methods and processes to make a product or gazette. The figure 5 shows student's level of learning the techniques, methods and processes to make a product during the course.

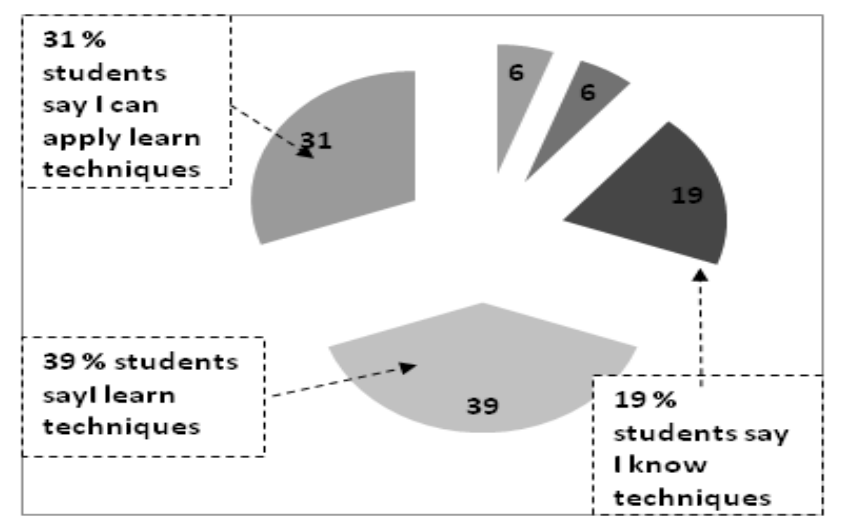

Figure: 5. Students level of learning techniques, methods and processes

One of the major focus is to introduce students to the use of power tools and ability to select appropriate power tool for 
specific application. The $30 \%$ of students have learned to use the power tools with on their own, $28 \%$ students have handled power tools and almost all students have ability to select appropriate tool for specific application. Another course outcome planned was to acquiring knowledge to choose process for making a product. All manufacturing processes such as metal cutting, metal forming and metal joining processes have demonstrated to all students.

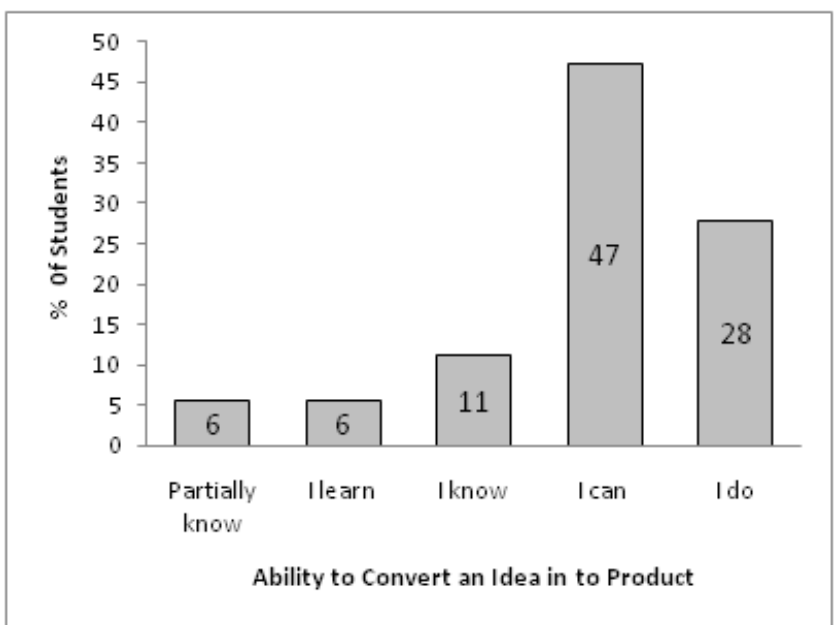

Figure: 6. Ability of students to convert an idea into a product

The students were evaluated for the ability to select appropriate manufacturing process and the results showed that $67 \%$ of students were able to select the correct process whereas $30 \%$ of the students just know the process and not able to select the correct process.

Knowledge of safety measures and use while working on machines was planned in the course. All safety cares while working with tools and machines were demonstrated to students and it is found that almost everyone was following the safety practices in the workshop.
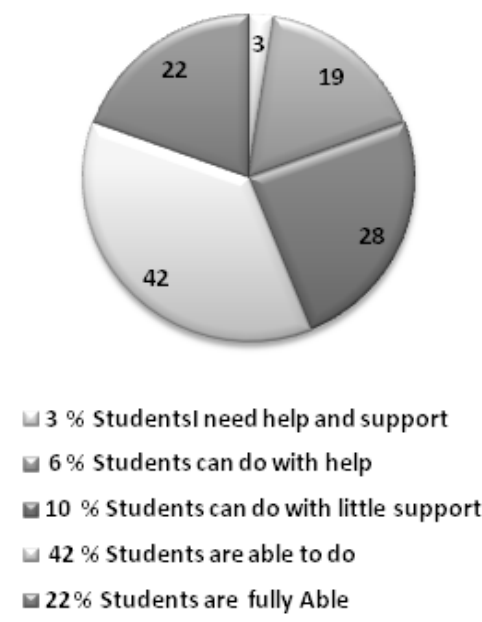

Figure: 7. Students capacity to make a product independently

The ultimate aim was to make students able to convert their creative ideas into the product and to choose right material and process to make it. This will help them in their professional life as they will be able to visualize the product development process and will be able to make cost analysis of the product. The figure 6 and figure 7 shows their abilities to convert an idea into a product with a creative way through the workshop practice and capacity to make a product independently.

\section{Conclusion}

The importance of integrating PPBL approach alongside the learning of engineering fundamentals, has been shared in this paper. In order to prepare students for their professional careers, engineering courses should be designed to assist students to acquire problem-solving and lifelong learning abilities, especially for the courses like workshop practice, integrating practical engineering design methods through projects are important rather than simply spoon feeding by demonstrating various skills. The attainments of the outcomes of newly designed workshop practice course with an approach of PPBL have shown considerable improvement in students learning. The student's approach towards workshop practice has been changed and they feel this course is useful them for their professional life. The knowledge about development of a product, its process has added value in students learning. The most important outcome of the course is all students including girls who always disliked this course also enjoyed this process of product development. This has become possible only because the fact that students have understood the potential of PPBL in which small products make an attempt to prepare students to face real-life problems. Project work towards product supports the development of life-long skills and student's autonomy. Therefore, engineering students who participate in PPBL would definitely have the better picture of the engineer's job. It can be concluded that PPBL is the best way to make future effective engineers.

\section{References:}

[1] Frank, M., Lavy, I. and Elata, D., Implementing the project-based learning approach in an academic engineering course. Inter. J. of Technol. and Design Educ., 13, 273-288 (2003).

[2] Mills, J.E. and Treagust, D.F., Engineering education - is problem based or project-based learning the answer? Australasian J. of Engng. Educ. (2003), 1 April 2016, http://www.aaee.com.au/journal/2003/ mills_treagust03.pdf [3] Bader Shamsan, A.T. Syed, "Evaluation of Problem Based Learning Course at College of Medicine, Qassim University, Saudi Arabia", International Journal of Health Sciences, Qassim University, Vol. 3, No.2, (July 2009/Jamada II 1430H) 249

[4] P.S.Jadhav, A.M. Mulla , P.M. Jadhav Anup Kumar, "Blending ICT with Project based Learning for effective teaching and learning of Mechatronics", Journal of Engineering Education Transformations, Volume 30, No. 3, January 2017, ISSN 2349-2473, eISSN 2394-1707

[5] Dr. Aruna Shekar, Massey University, "Project based Learning in Engineering Design Education: Sharing Best 
Practices," 2014 ASEE Annual Conference \& Exposition, June 15-18, 2014, Paper ID- \#10806

[6] Mukund V. Kavade, Sachin B. Khot, Martand Telsang, "Impact of IUCEE IGIP Engineering Educator's Certification Program on Teaching Performance of Participants", Journal of Engineering Education Transformations, Volume 30, No. 3, January 2017, ISSN 2349-2473, eISSN 2394-1707

[7] Lloyd, B.E., Ferguson, C., Palmer, S.R. and Rice, M., Engineering the Future: Preparing Professional Engineers for the 21th Century. Association of Professional Engineers. Histec Publications, Melbourne, Victoria (2001).

[8] De Graaff, E. and Kolmos A., Characteristics of problembased learning. Inter. J. of Engng. Educ., 19, 5, 657-662 (2003).

[9] ABET manual, http://www.abet.org [Accessed: Sept,2017]

[10] Walczak, M., Uziak, J., Oladiran, M.T., Baeza, C.C. and Paez, P.T., "Industry expectations of mechanical engineering graduates: a case study in Chile," Inter. Journal. of Engineering. Education., 29, 1, 181-192 (2013).

[11] Helle, L., Tynjäla, P. and Olkinuora, E., Project-based learning in post-secondary education - theory, practice and rubber sling shots. Higher Educ., 51, 287-314 (2006). 